гармонійного предметного середовища. I значимий слід Баухауз залишив не лише у Німеччині, але й на теренах Радянської України. Тому архітектурна та містобудівна спадщина конструктивізму у Запоріжжі (Селище № 6 або «Соцмісто») має універсальне значення, адже вона $\epsilon$ свідченням розвитку самостійного варіанту українського модернізму.

\title{
Література:
}

1. Кравчук П. Образи Нового міста. Універсальність явищ запорізького модернізму $i$ школи Баухаус. Проблеми збереження модерністської спадщини : матеріали до міжнар. наук.-практ. конф. Запоріжжя, 2017. С. 17.

2. Мьоссінгер В. Баухаус Запоріжжя: «Нове будівництво» в Україні та Німеччині. Універсальність явищ запорізького модернізму $і$ школи Баухаус. Проблеми збереження модерністської спадщини : матеріали до міжнар. наук.-практ. конф. Запоріжжя, 2017. С. 11-13.

3. Флієрп Т. Баухаус та конструктивізм. Універсальність явищ запорізького модернізму $i$ школи Баухаус. Проблеми збереження модерністської спадщини : матеріали до міжнар. наук.-практ. конф. Запоріжжя, 2017. С. 5-9.

4. Эфрусси Т.А. Баухауз на выставках в СССР. 1924-1932 гг. Актуальные проблемы теории и истории искусства: сб. науч. статей / под ред. А. В. Захаровой. СПб : НП-Принт, 2012, Вып. 2. С. 472-477.

DOI https://doi.org/10.30525/978-9934-26-004-9-74

\section{СТИЛІСТИКА РОМАНТИЗМУ У КАМЕРНО-ВОКАЛЬНІЙ МУЗИЦІ НІМЕЧЧИНИ ТА РОСІЇ (НА ПРИКЛАДІ ТВОРЧОГО ДОРОБКУ Р. ШУМАНА ТА П. І. ЧАЙКОВСЬКОГО)}

\section{Кравчук О. О.}

студент II курсу магістратури факультету музичного мистецтва Київського національного університету культури і мистецтв м. Київ, Украӥна

Романтичні ідеї внесли нові стильові особливості для розвитку камерно-вокальної музики. Кожна національна школа, що існувала як продовжувач композиторських традицій, або як новостворена національна школа, шукала свій особливий шлях в реалізації нових художньо-образних ідей. Вокальна спадщина тієї епохи сповнена 
поглибленої уваги до внутрішнього, духовного світу людини, психологізму, виокремлення національної самосвідомості, неймовірної краси та витонченості мелодики, $€$ безцінним надбанням світової музичної культури. Р. Шуман та П. І. Чайковський є видатними представниками епохи романтизму з яскраво окресленою національною стилістикою. Їх творчий доробок в камерно-вокальній музики по праву увійшов в скарбницю світової музичної культури.

Метою наукового дослідження $є$ виокремлення спільних та відмінних ознак романтичної стилістики у німецькому та російському музичному просторі на основі творів камерно-вокального жанру у творчості Р. Шумана та П. І. Чайковського.

Розглядаючи стильові особливості епохи романтизму в цих національних школах, ми можемо окреслити як спільні, так і відмінні риси. До характерних спільних ознак романтичного стилю німецької та російської вокальної музики належать: звернення до фольклорних та історичних джерел літератури, опора на національний мелос, національну поезію, людино-центризм. Варто відмітити, що окреслені стильові ознаки притаманні й іншим національним школам епохи Романтизму. Але саме в австро-німецькій і російській національних культурах вони дали надзвичайний поштовх вокальному, камерному виконавству. Ознаменувало розквіт камерно-вокального виконавства поява нових жанрових різновидів (цикли Lieder..) і переосмислення художньо-змістовного наповнення вже відомих жанрів.

Надзвичайно вагомим у творчості Р. Шумана $\epsilon$ камерно-вокальний жанр. За життя композитор створив чимало вокальних творів у камерновокальних жанрах: Lied, балади, пісні-сцени, цикли Lieder. У вокальних циклах Р. Шуман звертався до поезії Г. Гейне «Liederkreis» (Коло пісень), «Dichterliebe» (Любов поета), Й. фон Ейхендорфа «Liederkrei» (Коло пісень), А. фон Шаміссо «Frauenliebe und leben» (Любов і життя жінки), «7 Lieder» (Сім пісень пам'яті поетеси Слизавети Кульман) та Й. Гете, Ф. Рюккерта, Р. Бернса, Дж. Байрона. Композитор розкрив цілий світ художніх образів, створив драматично наповнені мініатюри. Реалізував ідею поєднання пісень в єдиний цикл через загальний тематизм. За твердженням російської музикознавиці В. Васіна-Гроссман, пісенний жанр став центральним у творчості Ф. Шуберта та Р. Шумана [2, с. 23].

Для творчості Чайковського теж характерним $є$ звернення до поезії національних російських поетів. Серед них А. Пушкін «Соловей», «Песня Земфиры», А. Толстой «Серенада Дон Жуана», "Средь шумного бала», А. Фета «Мой ангел, мой гений, мой друг...», «Уноси мое сердце», О. Плещеєва «Легенда», «Мой садик» та багато інших. В загальному, 
композитор написав більше 100 романсів. Коло образів романсової лірики Петра Чайковського надзвичайно широко відображає майже всі основні теми притаманні стилістиці романтизму. У творчому доробку П. І. Чайковського є філософсько-психологічні романси «Ни слова, о друг мой...», «Слеза дрожит», «Соловей». I безумовно серед видатних творів П. I. Чайковського $\epsilon$ зразки 3 глибоко-драматичним змістом, відтворенням максимально експресивних почуттів людини «Примирение», «Любовь мертвецуа», «Нет, только тот, кто знал». Також ми можемо побачити романси написані в стилізації народної пісні, що $є$ характерним для епохи романтизму зверненням до національних джерел «Кабы знала я, кабы ведала», «Я ли в поле да не травушка была». Також серед романсів Чайковського є відомі твори, які оспівують природу і асоціюють іiі 3 віхами людського життя «То было раннею весной».

Окреслюючи індивідуальні риси німецької та російської школи варто відмітити відмінності в жанрах, які розвивалися в період романтизму та в музичній мові.

На формування романтичної пісні в німецькій музиці вагомий вплив мав стиль зінгшпіля та німецької народної пісні. I саме в епоху Романтизму композитори Ф. Шуберт та Р. Шуман переосмислили звернення до цього жанру, та стали поєднувати пісні в один цикл. Завдяки об'єднання в циклічну форму жанр Lied отримує нові якості: сюжетність, наскрізність, можливість використовувати лейтмотивність. Таким чином він отримує i нове жанрово-стильове підгрунтя, що дозволяє його визначати як жанр нової Великої музичної форми.

Для композиторів російської школи, зокрема П. І. Чайковського, характерним було переосмислення жанру романсу. Романс - невеликий, самостійний музичний твір написаний на вірші поетів для голосу 3 супроводом (традиційно фортепіанним). У творчості російських композиторів зустрічаються випадки поєднання романсів у цикли, але традиційно це окремий, самостійний твір, часто баладного характеру. Але в творчості П. І. Чайковського і його послідовників цей жанр набуває нової змістовної глибини і вражає різноманітністю художньообразних ідей. У жанр романсу проникають формотворчі елементи 3 Великих форм (арій), що дозволяє розкрити в камерному жанрі складні філософські ідеї, внести елемент сюжетики, звернутись до деталізації психологічних образів. Наслідком такого переосмислення жанру стали великі романси-балади, романси-сцени, романси-монологи, так i навпаки, романси-мініатюри 3 надзвичайно насиченим змістовним наповненням (С. Рахманінов «Сон»). 
Варто зазначити не дивлячись на те, що кожна національна школа внесла свій індивідуальний внесок в розвиток світової музичної культури важливим узагальнюючим фактором $\epsilon$ у період романтизму трансформація романсової лірики в категорії салонної музики з ліричним змістом в твір з глибоким філософським осмисленням, емоційною драматургією засобами музичної виразності. За твердженням відомого російського музикознавця Б. Асаф'єва, «і Берліоз, і Шопен, і Ліст, і Шуман, i Мендельсон, i Вебер, i Глінка, i Шуберт, i Вагнер, i Чайковський, i Верді, і Бізе, і Гріг, і Брамс (...) - якими б різними не були їхні обдарування, глибина уяви, інтелект, смаки, характери, напрямки, творчі методи - всі спостерігали психіку людини та співчували неподоланним питанням про смисл життя, що виникали в людській свідомості» [1, с. 328].

\section{Література:}

1. Асафьев Б. Музыкальная форма как процесс. Москва: Музыка, $1971.376 \mathrm{c}$.

2. Васина-Гроссман В. Романтическая песня XIX века. Москва, 1966. $444 \mathrm{c}$.

3. Ду Чжоу. Образ автора в западноевропейской камерно-вокальной музыки романтического периода / Музичне мистеитво $і$ культура. 2016. № 22. C. $347-355$

4. Лігус О. М. Проблема дефініції романтизму: історіографічний аспект / Молодий вчений. Червень 2017. № 6 (46). С. 24-27.

5. Шип С. Музична форма. Від звуку до стиля. Київ: Забавит, $1998.368 \mathrm{c}$. 